\title{
Digital Wayang: Exploring the Use of Digital Media in Wayang Performance
}

\author{
Erandaru \\ Program Studi Desain Komunikasi Visual, Fakultas Seni dan Desain, Universitas Kristen Petra \\ Jalan Siwalankerto 121-131 Surabaya \\ Email: andar@peter.petra.ac.id
}

\begin{abstract}
Wayang is one of the traditional arts in Indonesia that once held an important aspect in Javanese culture. Wayang was used as a medium for religious rituals, education as well as entertainment. However, the advent of electronic media and the limited effort to maintain its relevancy with the contemporary audience have transformed and limit its present role within society as only a form of traditional entertainment. This journal documents a project that aims to explore the potential use of technology within wayang performance as an act of preservation through innovation. It shows how the innovative use of digital technology through its media could transform and augment the narrative aspect of wayang. It also provides insight in the design and development of digital media that takes into consideration the physical and philosophical aspect of local culture. Digital media is applied to wayang performance through the act of synthesis. Several characteristics of digital media, through the use of programming algorithm to control visualization, sound and interactivity, are used to augment the performance. The result is a contemporary form of wayang performance that enables live audience and data from the internet to transform the narrative and storytelling process.
\end{abstract}

Keywords: Wayang, digital media.

\begin{abstract}
Abstrak
Wayang merupakan salah satu seni tradisi di Indonesia yang pernah memiliki posisi penting dalam budaya Jawa. Selain memiliki peran penting dalam ritual religi wayang juga berperan sebagai media dalam pendidikan dan hiburan. Tetapi seiring dengan perkembangan teknologi dan kurangnya usaha untuk mempertahankan relevansi keberadaannya dengan pemirsa kontemporer telah merubah dan membatasi peran wayang di masyarakat menjadi sekedar media hiburan tradisional. Jurnal ini mendokumentasikan secara ringkas sebuah proyek yang bertujuan untuk mengeksplorasi potensi aplikasi teknologi digital dalam kesenian wayang sebagai wujud pelestarian melalui inovasi. Aplikasi teknologi digital dalam elemen audio visual kesenian wayang secara inovatif dapat merubah dan memperkaya unsur naratif wayang. Proyek tersebut juga bertujuan untuk mengekplorasi aplikasi aspek fisik dan nilainilai tradisi dalam wayang yang dapat bermanfaat dalam pengembangan media digital. Media digital diaplikasikan dalam pertunjukan wayang secara sintesis. Karakter media melalui algoritma pemograman digunakan untuk mengatur visualisasi, suara dan interaktifitas yang bermanfaat dalam memperkaya pertunjukan. Sintesa tersebut memungkinkan munculnya suatu bentuk baru pertunjukan wayang yang diharapkan memiliki relevansi dengan permirsa kontemporer.
\end{abstract}

Kata kunci: Wayang, media digital.

\section{Introduction}

The advent of new media is always accompanied by friction with the traditional, a form of dialectic that shapes the culture as well as the development of the media. The same applies to the advent of digital media within modern societies. Like most countries with a strong traditional culture heritage, Indonesia's modern culture is a result of confrontation and compromise between the old and the new. The dichotomy between traditional values and modern values in the form of traditional arts and modern entertainment has cause friction, although not in the physical senses, still leaves a question on the future survival and existence of traditional arts and value, and giving doubt on technologies as a vehicle of value.

Confrontation is always being a part of a culture progress. The problem lies if the confrontation only reaches the boundary of friction, with a resulting tendency from both sides to retreat slowly in the process. Posing a threat that a convergence between the two would never took place. 
It is obvious that the rise of technology, through the invention of digital technology and the ubiquity of internet as one of its product, and the changes it brings is inevitable. Instead of accepting the fact and by doing so treating this technology with cautious and criticism that would be valuable for the future development of the technology, the traditionalist has the tendency to rejects and choose to avoid the use of this technology. An act of prejudice as this technology is often blamed upon to be the source of moral degradation.

On the other hand the modernist has the tendency to be over excited with the progress technology has made possible, failing to tread cautiously in embracing every product that this new technology has brought. They presume that tradition is something of the past and obsolete, judging those that maintain true to tradition as an obstacle of progress.

As tradition has a strong tie with traditional arts, this dichotomy also appears in the art world, a fact that has been criticized by Michele and Robert Root-Bernstein (2010), commenting that it is a general misconception for people to view art and technology as antithetical to each other.

In Indonesian art community, Murtiyoso (2009) notes that the ubiquity of digital technology has brought upon reaction from traditional artist and as a result the shape of Indonesian traditional performance arts could be categorized into 4 groups:

- Conservative, this group maintains a conservative and purist approach, considers globalization as a threat.

- Commercial, this group considers traditional arts as pure entertainment.

- Progressive, as usually represented and practice by the academic community, this group always experimenting and exploring new territories.

- Moderate, this group chooses to try to maintain the balance between act of conservative as well as commercial. Market oriented while still trying to be true with tradition.

Hi Kyung Kim at the Tradition/Innovation Conundrum (UNESCO 2nd World Conference on Arts Education, 2010) mentions that artists whose art are based on traditional heritage often has to face three options: to act conservatively, contemporary, and synthesis. She points out that by being conservative actually pose the risk of traditional art to become extinct, because it does not allow room for the art to progress with society, becoming more and more irrelevant with the society as time progresses. The contemporary approach could help in reviving traditional art, although might pose the danger of distorting the original concept of the art. Kim strongly suggest the act of synthesis, carefully selecting and combining the best of both worlds to create something original that still maintains the important aspect of traditional value that could progress through generations (Michele and Robert Root-Bernstein, 2010).

This journal documents a project by the author to explore these following questions:

1. Is digital media suitable to be used in traditional arts?

2. If so how we could make use of the digital media to augment traditional arts performance?

3. How concept from traditional culture (which embodies within traditional arts) could influence digital media design and development?

The value of this project is to give insights from both perspective, encouraging the preservation of traditional arts through act of evolving and innovating and at the same time mining valuable traditional concept and philosophy that we could use in developing new media.

Since Indonesia has a very diverse culture, it has many traditional arts to choose from as the embodiment of this project. Wayang is chosen based on these following reasons:

- Wayang combines several aspects of traditional arts, theatre, dance, painting, crafts, sculpting and music. It provides an ideal environment to explore digital media capabilities to span multiple forms of arts.

- Wayang once hold an important value in educating values and a source of reflection and contemplation for the people. It has been in the business far longer than digital media. Although the culture has changed, there must be something that could be learned from wayang that is valuable for the development of digital media.

The method uses to explore these questions is first to do a literature research on wayang in order to understand about wayang, its properties, purposes and evolution, the same also applies for digital media. The result of this analysis is used to create a hypothesis on how the two relates.

Studies to examine previous attempts in the application of digital media in a wayang performance are also important. It will help to gather further insights of what have been done and its results. Once an understanding of the nature of the 
relationship is achieved, the second step is to take into account those relations in defining design concept to implements within a project. The third step is to analyse the result and performance of the relationship.

\section{Analysis}

\section{Analysis of Literature and Previous Works}

Wayang is one of Indonesia's oldest traditional performance arts. Supriyono suggests that it dates back from the $907 \mathrm{AD}$ and supposedly to be of Indian origin. It is a form of traditional storytelling that makes use of animated shadows cast from puppets controlled by a puppeteer (2008).

According to Ulbricht the philosophy behind the use of shadow in wayang performance stems from ancient beliefs on the existence of spirits and its importance in human life (1970). The spirits has no embodiment, and unlike everything else on earth it has no physical properties. Since it has no apparent physical properties it is impossible to portray spirits as something visible. Hence the use of shadow to portray spirits, as its character considered to be a close resemblance that of the spirits. The shadow has no physical properties besides being visible, in which that as the result of the existence of a source of light.

Wayang origins that is purposely conceived as a medium to link with the spiritual world make it to be considered sacred and holds a mystical value. This is why traditional wayang performance is only performed during special occasions.

Although the root is of foreign source, over the course of time wayang has evolved, transforming its shape and form with distinctive properties that differentiates it from other type of shadow puppet which makes it a unique product of Indonesian traditional culture. There are several factors that influenced the evolution of wayang performance: politics, religions, and beliefs. These factors influence the performance's storyline as well as its form.

There are 4 main elements of a wayang performance: the lakon (story), the dalang (puppeteer), the wayang puppet, and the audience. The following paragraphs explore each of these elements and its significance within the performance.

\section{The Lakon (story)}

The storyline in a wayang performance always narrates the conflict between the good and the bad, where the good always prevail in the end of the story. Most of the stories are excerpted from the Hindu mythology (Ramayana and Mahabharata epoch) that has been modified with local beliefs and preferences in the process. Some romantic stories are based on traditional folklore or legends.

\section{The Dalang (puppeteer)}

The dalang has a very important role in a wayang performance, with the exclusion of wayang wong. The Javanese culture regards the dalang as a guru, guiding the wayang audience in communicating with the spiritual world (Ulbricht 1970).

According to Supiyono the word dalang has several meanings. The Wedha (Buddhist holy book) described it as someone with the capacity and obligation to give guidance, teach and translate the Wedha and its meanings to the people. Dalang could also be referred to as dalung or blencong, a traditional lamp. It has symbolical meaning that dalang must enlighten. Another source of meaning for the word comes from the phrase Angudal Piwulang. Angudal means to tell a story, to describe, to say and explain what is in one heart. Piwulang means wise teaching or advice; it means that a dalang is someone who teaches by means of story or a storyteller. Dalang could also be traced to the word Talang that means water gutter on top of a roof. Similar to the functions of a water gutter that collects the falling rain on top of the roof and channeled it down to the ground, a dalang represents the link between heaven and earth, the men and the spirit world, channeling spiritual wisdom to mankind. From all those meaning it could be summarized that dalang is a spiritual teacher that guides and enlightens people by means of storytelling using shadow puppet.

\section{The audience}

According to Ulbricht the audience in a wayang performance has a symbolical meaning. The wayang storyline are meant to represents the evolution and development of mankind. It unfolds the journey from the man of the past that have met its fate to the man of the future that has yet to fulfil its destiny. In the middle lies the present man that is represented by the audience.

It is interesting to note that although the audience represents a stage of the storyline, they only act as spectator. They have a symbolical value within the performance but they have no active part in the storytelling process. Ulbricht did not give any further explanation regarding this particular condition. 
In my opinion there could be two reasons. The first if we associate with the history of wayang performance that holds a religious importance, it has the quality of being sacred. The involvement of audience could potentially disrupt the sacredness of the performance. The second if we associate with the narrative process in which according to Clarke and Mitchell the narrative should be told by the storyteller (Brown et al). The audience involvement, if not properly controlled by the dalang could distort the narrative process.

During the performance of traditional wayang the audience is facing the part of the screen that displays the shadow. The audience and the dalang have no visual contact as the dalang is hidden from the audience gaze by the screen. However, today most audience view the performance from behind the dalang; presumably as the performance of the dalang in animating the puppet is considered to be a more interesting spectacle compared to the unfolding of the stories.

\section{The wayang puppet}

As mentioned in the previous paragraph, wayang has undergone numerous transformations in the course of its evolution. One of the most prominent took place during the expansion of Islam as a religion in Java. The wali sanga, Islam missionaries in Java, forbids the portrayal of wayang puppet characters as human likeness for it is against the teaching in Qur'an. However instead of forbidding the performance, they took a more elegant approach by mandating an order to modify the shape of the human portrayal, distorting most of its anatomical proportions such that it does not appear to be human anymore. This modification defines the visual style of Javanese shadow puppet up until present.

Wayang has been known to be made from several different type of material. The most common is made from buffalo hide, while the most odd would be that being performed by actors instead of puppets. History has recorded that wayang has been made from hay, dried palm tree leaves, paper, wood, buffalo hide, bark cloth and as previously mentioned is performed by live performers.

The choice of materials directly influences how it is being performed. Wayang beber, as an example, is a type of wayang that is drawn on a long scroll of bark cloth, the story progress linearly in accordance with the unfolding of the scroll. The story telling process in wayang kulit (made from buffalo hide) performance is by animating the puppets. While the wayang wong (human actors) tells the story through the act of the performers on the stage.

The wayang performance as a form of art is fluid and malleable. These are important characteristic that makes it endure the course of time. It adapts to changes and flexible enough to accept progress, resulting to the various type of wayang performance as it is known today.

The visual appearance of wayang demonstrates an exceptional design and craftsmanship skill to integrate symbolic messages within visually aesthetic shapes and patterns while making most of the material.

The wayang performance in itself is a medium, capable of conveying messages to the audience. Where once it is used in religious teachings, it has traversed beyond the boundary of theology, serving purposes from pure entertainment to the sociallization of government policy.

The storytelling process in traditional wayang performance is linear and, with the exception of wayang wong, in the form of monologue. It has no direct interaction with the audience. This placed the dalang in the central position of a wayang performance. The success of the performance is highly dependent on the wisdom and skill of the dalang in animating and performing the puppet character while also conducting the accompanying gamelan orchestra.

\section{Digital Media}

The common definition for digital media is an electronic media that works based on the digital technology. Whereas digital technology is an ingenious invention that makes use of simple codes as combinations of numbers (e.g. in a binary system 0 and 1 each respectively represents a state of on or off similar to that of a switch) to control the flow of current within an electronic component. Once combined in a string of code, it opens the possibility to create numerous alternative configurations of states. These codes will be translated by electronic device by means of a decoder (i.e. a software embedded within the device) giving instructions on how the device should operates.

Marie-Laure Ryan (2004) mentions 5 distinctive properties of digital media:

- Reactive and interactive nature

- Multiple sensory and semiotic channels

- Networking capabilities

- Fluid and dynamic nature

- Modularity 
Reactive is the capability to react to unintentional stimuli (eg. changing temperature in the weather), interactive is the capability to react to intentional stimuli (eg. the click of a button). Multiple sensory and semiotic channels is the capability to receive and recognize stimuli from more than 1 sense (sight, sound, tactile). Networking capabilities make it possible to connect multiple devices, sending and receiving data and information from one device to another (fluid), making it possible for the availability of dynamic data (always up to date). While modularity makes it possible to develop an application in a more efficient manner, starting with the main module and building it up by adding more modules with different functions and capabilities. Each module developed by different teams working in parralel, reducing development time and cost.

WithThe digital technology give birth to a new media that is fluid (the ability to transverses multiple channel), malleable and capable of mimicry, simulating the properties of nature.

\section{The Use of Digital Media in Wayang Perfor- mance}

Several contemporary dalang in Indonesia has integrated the use of digital technology within their performance. Mostly in the form of overlaying the wayang screen with images and/or video clips projected from LCD projector, enhancing visual performance with digitally created content. So far there are no reports of performance in Indonesia that has made use the distinctive properties of digital media as proposed by Ryan (2004). Presumably there has not yet been any effort of collaboration between artists and programmers, a case that could be suspected as a result of the dichotomy between traditional and modern (technology) such that has been addressed in the beginning of this paper.

However in 2007 a collaborative performance performed by I Gusti Putu Sudarta, Semi Ryu, Stefanno Faralli, Andrew Clay McGraw, John Macdonald, Taylor Burton, Deven Langston, and Christopher Romero as part of research project explore the use of digital media interactivity within wayang performance. The project draws on the concept of traditional wayang performance in Bali and its purpose is to explore how performer and audience response to mixed reality between physical and virtual objects (Ryu).

The puppeteer in the project has the ability to control physical puppet as well as the virtual one. Visual and audio sensors are used to capture puppeteer voices and actions which are then converted into streams of data to control the virtual puppet. Audience is also given the chance to participate interactively with the performance by creating virtual environment for the background that the puppeteer could interact with.

The project demonstrates that this collaboration created a rich entertaining experience for the audience. The introduction of new media within the performance does not appear to disrupt the dalang's capability to perform and entertain, in contrary it provide the means for dalang to exploit his creative potentials as a performer.

Unfortunately these collaborative projects only practiced behind the confines of academic wall and rarely performed to the masses, one of the distinct characters of progressive yet idealistic arts that Murtiyoso has pointed out. While it may produce valuable insights, it is useless as wayang performance as a medium to convey message has to communicate to the masses. Something that so far has been successful in the flexible and consumer oriented arts.

There has been effort to introduce the use of digital media in a wayang performance although in terms of quality has not yet use the potential of the media.

\section{Synthesis}

The main purpose of this project is to challenge the dichotomy of traditional and modern (art and technology). This could be achieved by creating a project that integrates the two groups into one collaborative effort. By collaborative meaning that there has to be an interactive communication and action between the two group, resulting that the collaboration will contribute to each other. But to be able to do so, first there has to be a clear distinction between the two on what role or its position within this collaboration.

It is clear that the modern (technology) acts as the media, a platform for the traditional to shape and built the performance upon. It will successfully make use of the media if he/she could exploit the properties of digital media as mentioned by Ryan (2004). It is then important to define one of the requirements of the design is to use digital media capability to convey philosophical meanings.

The beauty of traditional art is its consciousness to the environment, physical as well as spiritual. It produces artefacts with beautiful ornaments that draw its inspiration from nature. Motion in dances 
are inspired by the gesture and grace of animals, the beauty and elegance of flowers swaying in the wind, and the clean refreshing rush of waters along the river banks. The traditional art also recognize the importance of living as community, where traditional rituals are carried out as a gesture of gratefulness and usually performed by the whole community. These important elements of traditional art should be an inspiration for the development of digital media. The presentation of data and information should be more elegant, considering into account the nature of the data not only as number, but has story to tell. Data could be used as a medium for storytelling. The same also applies for digital media networking capability; technology should be made to give a better knowledge to user on how their every action in the network would eventually triggers reaction, and depending on the nature of these interactions could lead into something aesthetic.

The traditional art values the previous generations, something that digital media could use. As we notice there are already a huge number of redundant data in the internet clouds. These data should have value that could be used in some way. So far there has been no obvious effort to create and use data more wisely.

Based on analysis of data gathered from the previous chapter, the requirements for the project's design as the following:

- Performance must incorporate the use of sight, sound and interactivity.

- There will be two users that interact with the performance. The dalang (puppeteer) that interacts ontologically (defines the courses of the narrative), and the audiences that interacts within an exploratory mode (has no effect on the narrative courses).

- The dalang will control the main and supporting character as well as unfolding the course of the story.

- The audiences' involvement is in the form of collaborating with the puppeteer to perform a certain task.

- Other elements (environment and non-playable characters) within the performance are reactive (interacts with the environment) instead of interactive. It will react to data from the motion of the playable characters.

- The audiences' interface must be simple to operate and inexpensive.

- The performance's sight and sound must make use of digital programming as a way to symbolize and convey philosophical meanings (e.g. the use of mathematical formulas in the programming code to simulate the seemingly chaotic motions of nature).
- The performance should use collective data from the internet as means to enriched narrative with contextual information from contemporary time.

- The technology platform must provide and encourage artist to explore and experiment with new approach and possibilities in creativity, enriching the art in the process.

\section{Design Development}

\section{Main Application}

In the initial state of design development there are several alternatives of software that met the criteria required by design concept to create the project's main application, Open Frameworks (developed by Zachary Lieberman in 2005) and Processing (a project initiated by Ben Fry and Casey Reas in 2001). Both software are opensource, meaning that it is distributed under the creative commons license, making it available for free and open for modification. Thus, it provides the user a platform for ease in modifying the main application according to the user's needs. It also provides a low-cost means to learn programming and developing digital media.

Internet researches that compare both software suggested OpenFrameworks as a more ideal solution as it promises the ability to handle complex large scale projects that requires extensive use of the CPU's processing power and memory. However Processing is chosen, as the language is easier to learn than OpenFrameworks.

As open-source software distributed under the creative commons license, both has an active online forum and sites that provides users with support and library of plug-ins as well as collection of codes shared by other users. These are the positive characteristics of open-source software, as it creates an environment for people to create, share and collaborate. It is these practices and communities that are more significant than the software itself (Kelty).

The design of the application is divided into five main components; screen, environment, character, interactivity and HCI component. The screen component controls the main look and feel of the screen projection (screen size and aspect ratio, screen flicker to mimic the appearance of traditional wayang screen, gradation, and color). The environment component controls the construction and behaviour of environmental objects (terrain and vegetations). Character component controls the construction, behaviour and manipulation of 
character objects (puppet). Interactivity controls how audience interacts with the performance. HCI component controls input devices for user (dalang) to interact physically with the virtual character as well as to operate the application.

\section{Screen Component}

The screen component is designed to reproduce the appearance of traditional wayang screen. A screen ratio of $16: 9$ is used to compromise between maintaining the look and feel of traditional wayang screen and optimizing the use of projector screen size. Screen size is set to $800 \times 450$ pixels as it is the most optimal resolution. An increase of resolution more than $800 \times 450$ could significantly cause a dramatic drop of frame rate. Flicker is added to mimic the quality of traditional performance. It has the purpose to symbolically represent the nature as not being predictable.

The screen component also controls the colour of screen, which in the case of this project is designed to display gradation of grey for the opening of the scene, gradient of blue during the first scene, gradient of green for the second scene (undersea), and red gradient during the fight scene. The colour is supposed to enhance the emotional atmosphere of the scene.

\section{Environmental Component}

The environment makes use of perlin noise, a formula that creates regenerative patterns, making it possible to modify the pattern of the noise by changing variables instead of images. In this project the clouds turns into an ocean by simply modifying its value. This reflects the characteristic of $\mathrm{H}_{2} \mathrm{O}$, a molecule that could be found in three different states in nature, liquid, solid and gas; depending on the speed (the value) of the molecule.

The tree sways and scrolls according to its position relative to the screen. The higher the tree the more it sways, while during scrolling the taller trees moves faster than the smaller tree, creating the illusion of depth.

The motion of the clouds and trees is dependent on the main character. It will always scrolls to the opposite direction the character is facing. And the faster the character moves, the faster the background will scroll.

\section{Character Component}

The characters are created from the same Class. Instances of this class will have different properties resulting in a different physical appearance for each character. This programming technique is also known as OOP (object-oriented programming).

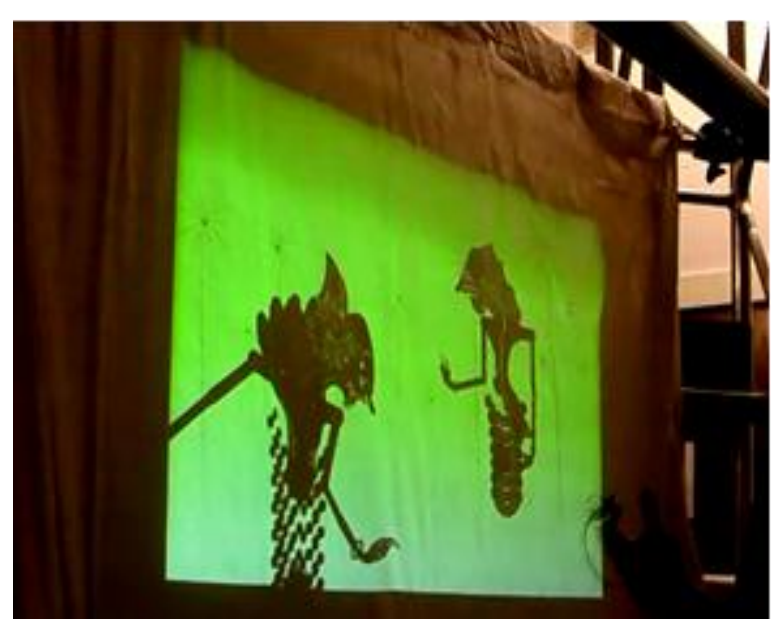

Fig. 1. Characters and environment

In programming perspective, OOP provides ease and efficient use of coding for application. From philosophical perspective it could be viewed as a metaphor of how different characters are essentially one; coming from a singular sources, equal in its basic form.

\section{Interactivity}

Interactivity will be introduced as part of the narrative process, but as not to interfere with the lakon; it should not be in the form of total interaction. It could rather be in the form of contribution as demonstrated by Semi Ryu. Audience participation could be limited in some extent such as that it will not disrupt the flow of the story.

The project requires the audience to take part by a form of collaborative action with the performer. During the performance audience are expected to clap their hands during the fight scene each time the sea dragon attacks the main character. A microphone will capture the clapping noise and compared its pattern with data of a previously recorded noise pattern within the program. If the comparison result is a match between the patterns, the main character could perform a special move to defeat the sea dragon.

A passive collaborative action is also integrated within the project. Programming algorithm is made to search the internet through Google API for words conveying basic human emotions (i.e. angry, happy, sad, disgust etc.). Every two minutes each word is contested to find the most word searched in Google within that time frame. Word with the biggest search number will tint the environment with color that psychologically represents the conveyed emotion. For instance, angry will change the environment to a reddish hue, sad to a bluish hue, orange for happy mood, etc. 


\section{Human Computer Interface Devices}

\section{Keyboard}

Keyboard is still used as input especially for the environment and character creation process. The preliminary design requires the use of voice activated command using GlovePIE to give freedom for the performer (dalang), however during the design development process it proves to be causing more glitches rather than working normally. Character would come out even though it is not called by the performer. This problem is probably because the nature of the software that does not respond very well to voices. However voice activated command could result perfectly to augment the wayang performance, as demonstrated by the Experimental Virtual Wayang projects (Ryu et al.).

\section{Gametrak}

The gametrak is a controller device purposely designed for Real World Golf game. It has a working mechanism similar to that of a joystick with the addition of a retractable cable. The base of the controller provides 2-axis motion direction, while the retractable cable provides distance in the third axis. The device is also equipped with a detachable hat button that provides switch (ON/OFF) state as well as direction.

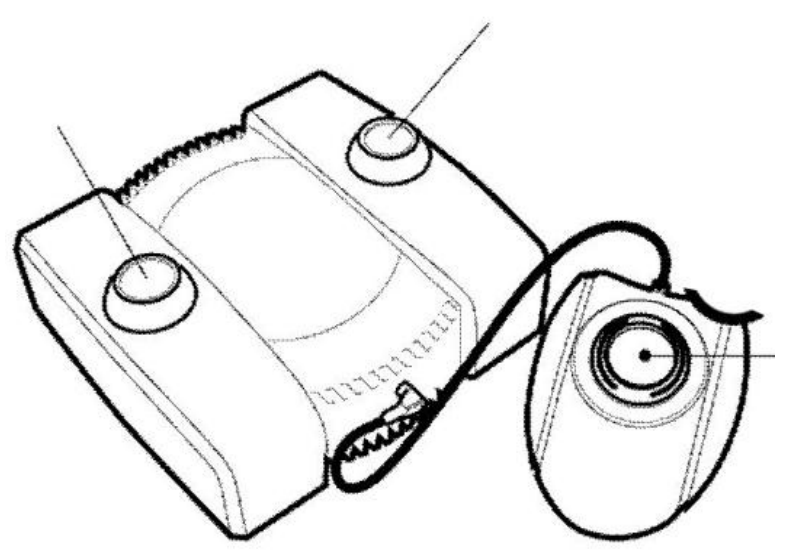

Fig. 2. Gametrak

Gametrak is relatively easy to connect to Processing through the proControll library since basically the Gametrak is similar to that of a joystick. It will read as a joystick with 7-input data, the X-Y-Z axis translation, the X-Y-Z axis rotation and the button's ON/OFF state. However adjustment has to be made in Processing for calibrating the data input from the device to relatively match the size of the display screen and the motion and direction of marker.
The performance's environments and possibly the performer could differ from one place to another. Differences in screen size, screen position, performer's height are the main parameter that could affect the initial setup of the device. Providing functions in Processing to calibrate the device will provide ease and convenience for the setup process.

The logic behind the calibrating functions is to capture the $\mathrm{X}$-axis translation/rotation and Z-axis translation/rotation values sent by Gametrak and map that data to the screen size. The calibration process requires three steps of action for each hand as described below:

- Right hand: first step is to position hand at the upper right corner of the screen and capture the data location, second step it to position hand at the lower left corner of the screen and capture the data location, the third step is to calculate the boundaries for the right hand based on the data location and use of Pythagorean theorem.

- Left hand: a mirrored version of the right hand steps. Starting by collecting location data of the upper left corner and followed by the lower right corner.

The slight difference between the right hand and the left hand calibrating process is due to ergonomic consideration, especially when the performer is in a static position. It is easier to reach the upper part of the screen rather than the bottom because the position of the arm is located on the upper part of the body.

The calibrating process described above provides a fair accuracy in tracking performer's hand position, though not recommended for larger screen size. A more accurate calibration could be achieved by capturing more reference point from the screen and taking into accounts the Y-axis translation/ rotation to the calibration functions.

Gametrak ingenious feature (the retractable cable) ironically is also its weakness. It provides a more stable and predictable data (compared to Wiimote IR sensor or accelerometer), but limiting performer's freedom of movement. The cable has a limited length and its physical properties make it impossible for the performer to rotate his/her body. The performer has to maintain a consistent facing position relative to the screen; otherwise the two cables would tangle together.

\section{Wiimote}

The initial design process was to use Wiimote IR sensor to capture performer's hands position relative to the screen, but experiments result shows 
that position data sent from Wïmote behaved erratically. This could be cause by several factors, the Wiimote device itself, the conversion process from Wiimote output to OSC, and/or the environment lighting where the experiments were conducted.

The problem could be solved by using matrix. Several data from Wiimote could be captured in the form of a matrix, and a single value could be sent to OSC from the average value of the components within the matrix. However it would still pose a problem if the value differences are high.

In the final state of the project Wiimote IR sensor is only uses to capture the state of IR LED (on/off). It has a function similar to that of a mouse button; it activates the controller each time the IR LED turns on. It is based on Johnny Chueng Lee's creative idea. Instead of moving the Wiimote, it is positioned in a static location, while the IR LED is positioned at the performer's hands. This gives the possibility to make a simple device consisting of an IR LED, a resistor, a tactile switch and $3 \mathrm{~V}$ battery; small and light enough to be fitted to the performer's hands.

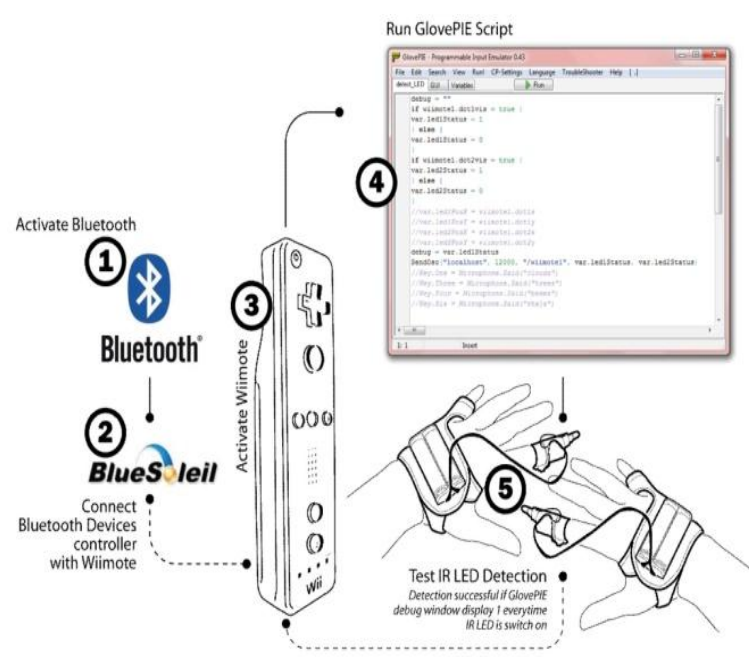

Fig. 3. Wiimote and GlovePIE setup

IR LED active state is transmitted to GlovePIE through Bluetooth connection. GlovePIE is a free software developed by Carl Kenner. It is an emulator for input devices. This project makes use of GlovePIE capability to capture IR data from Wiimote and convert it to OSC (open sound control), a format that could be read by Processing. Although the connection process requires several attempts, once connected it provides a stable stream of data from Wiimote.

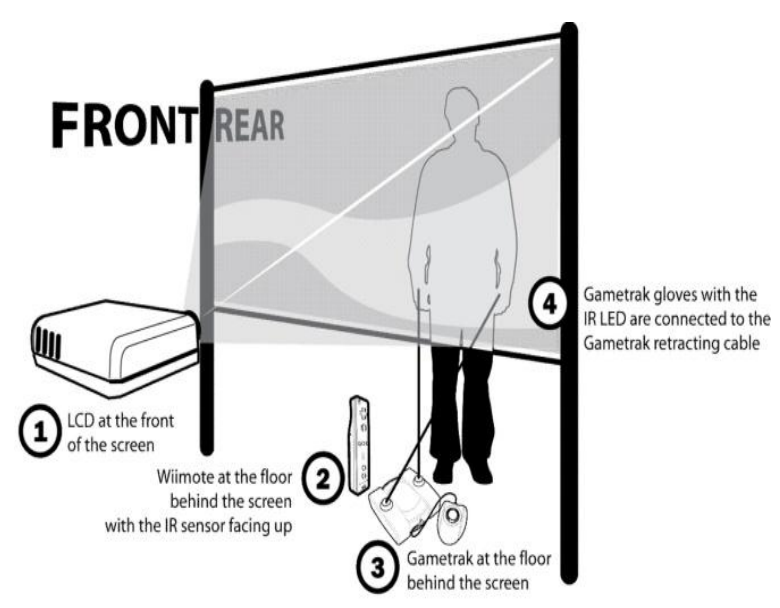

Fig. 4. Devices setup

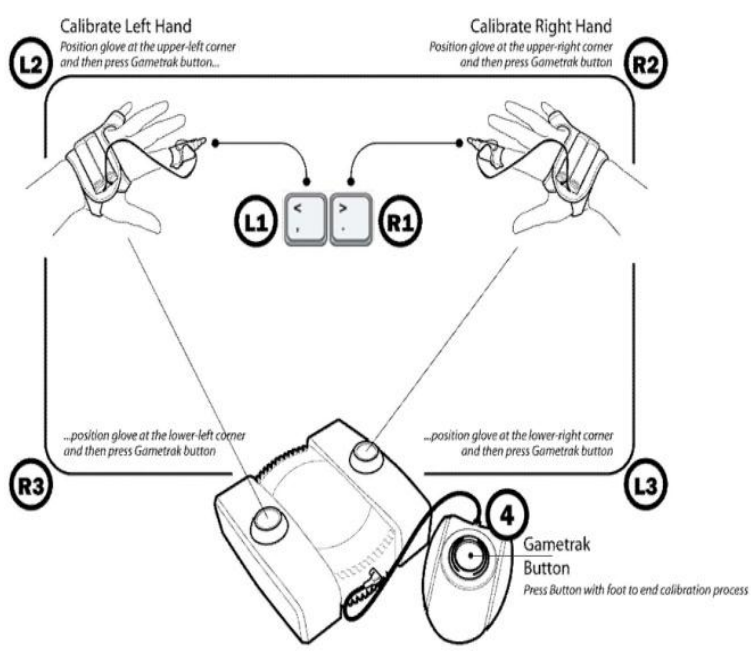

Fig. 5. Screen calibration

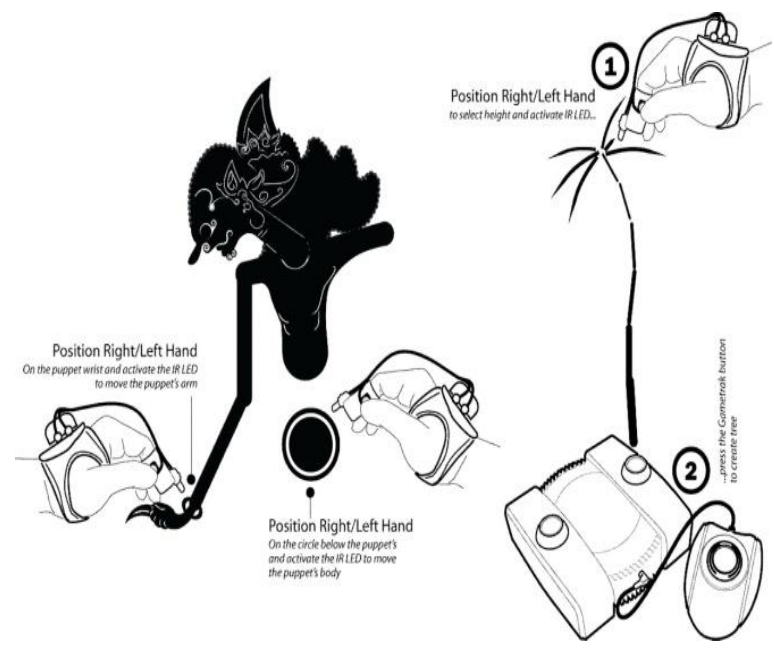

Fig. 6. User Interface to control the puppet and creating environment 


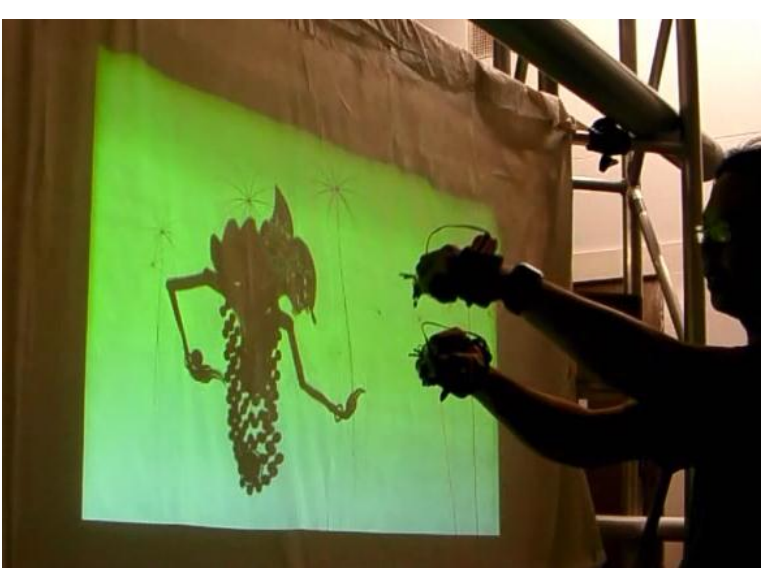

Fig. 7. Controlling the wayang character

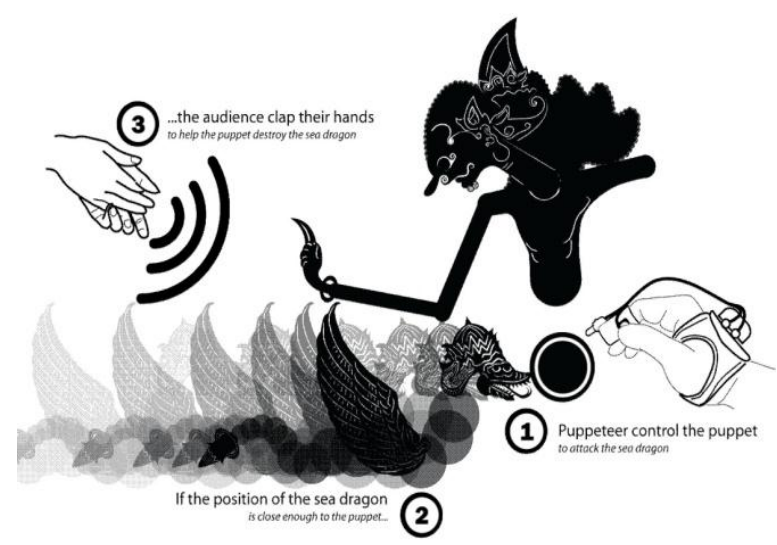

Fig. 8. Audience collaboration

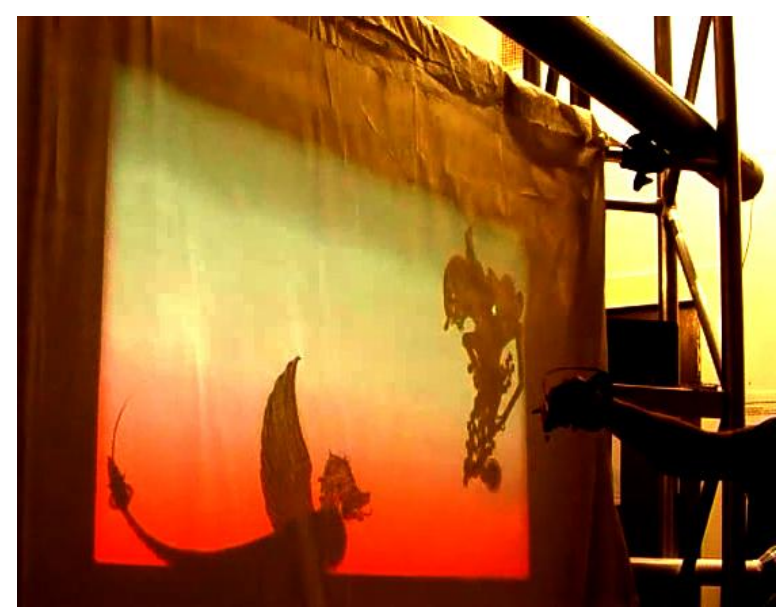

Fig. 9. Fight scene

The combined application of Gametrak and Wiimote as the performer's controller may not look practical. However it provides the best results based on value to performance ratio. It delivers motion tracking capability at a very affordable price and does not require complicated hardware hacking. Their weaknesses are the limited freedom of movement, not yet capable of providing physical feedback to the performer, the requirement of initial setup time and the availability of the devices in the future (as it is supposed to be hardware designed and manufactured for proprietary game console and software there is no guarantee that the hardware will continue to be developed and produced in the future).

\section{Summary}

The ubiquity of media based on digital technology has led the way to its application in traditional art performance. However, most traditional artist has limited knowledge of this technology. A condition which could be blamed in part on a classic assumption that tradition and technology does not mix well together. The lack of knowledge of the media has limited its potential use to convey the art philosophical concept to the audience.

Therefore, it is important to give insight to traditional artist the characteristics of digital media, as well as providing a real example on how it could be used to augment the artist performance, providing innovative approach in the narrative process that could meet the contemporary audience characteristics.

It is also important to note that traditional values could be used as references in developing digital media applications. The extensive use of symbols and metaphor in traditional wayang performance could give insight on how digital media should apply the same approach in providing the means for human-to-human and human-to-computer communication and interaction. This hopefully will provide a more interesting, elegant and engaging user experience, embracing user within a modern approach of communication and interaction that is based on traditional values. It could assist in minimizing user discomfort in adapting to new media, as well as preserving the traditional customs that are still relevant with contemporary custom.

\section{Conclusions}

The general assumption that art and technology are contradictory to each other is not true. The project has demonstrated that digital media has the properties capable of representing traditional values. It is made of codes that could interact with other codes that have the capability to represent meanings through the use of medium across different channel (visual and audio).

Digital contemporary art requires the artists to understand the underlying concept and code in 
programming language and/or scripts. As is with other media, a thorough knowledge of the medium and its properties provides artists with more freedom of creativity in constructing and shaping digital media.

The indirect nature of traditional arts and its ability to convey messages in a more elegant manner through the use of symbols and metaphor could give insight on how we represent data through digital media and how communication within network should incorporate aesthetic value.

In the course of history, change is a necessity and inevitable. The question is how to make use of this change that best serves our needs rather than our wants, embracing progress while maintaining true to who we are.

\section{Recommendations}

Future experimental projects in the implementation of digital media in a wayang performance should explore the possibility of using the media that gives freedom to performers in exploring different techniques during the storytelling process. As an example Ki Enthus spontaneously represents himself as part of the puppet, interacting with his puppet directly.

Experiment should explore the use of multilayer that is reconstructed around the performer as a way to immerse performer within the wayang world, where his/her interaction with this virtual world could augment the story telling process.

The experiment should explore the possibility for a multi-puppeteer environment, connecting several puppeteers through network connection and encouraging to experiments playing live simultaneously and interactively, such as that interactivity would span multi performer.

During the production stage of this project, new technologies in physical motion capture devices such as Kinect has not yet been available in the market. The advent and ubiquity of these devices will provide an easier setup environment for artists as well as opening new possibility for creativity. A culture of experimenting and sharing is a must for artists in exploring the use of these devices for their works and performances.

\section{References}

dhiarrgombez. (2008, 3 October). Wayang Kulit Multimedia-Gatotkaca Lahir. Retrieved from http://www.youtube.com/watch?v=Wj5pt5sH3 Tk
Jclm5. (2007, 7 December). Low-Cost Multi-touch Whiteboard using the Wiimote [Video file]. Retrieved from http://www.youtube.com/ watch?v $=5 \mathrm{~s} 5 \mathrm{EvhHy} 7 \mathrm{eQ}$

Kelty, Christopher M. Introduction. Two Bits: the Cultural Significance of Free Software. Durham: Duke UP, 2008. Print.

Kitchenbudapest. (2008, 19 February). Reverse Shadow Puppet [Video file]. Retrieved from http://www.youtube.com/watch?v=gY2dC9fi02s

Murtiyoso, Bambang. "Prospek Seni Budaya Indonesia Dalam Menghadapi Era Persaingan Iptek \& Era Global." E-wayang. Kelompok Studi E-wayang Indonesia, 3 Dec. 2009. Web. 19 Aug. 2010.

$<$ http://www.e-wayang.org/index.php/en/article/49artikel/66-prospek-seni-budaya indonesiadalammenghadapi-era-persaingan-iptek-a-era-global. html>.

Rhoughtonny. (2008, 22 February). Indonesian Shadow Puppet Show. Retrieved from http://www.youtube.com/watch?v=6fVxPoRu2 bw

Root-Bernstein, Michele, and Robert Root-Bernstein. "The Tradition/Innovation Conundrum: Further Reflections on the UNESCO 2nd World Conference on Arts Education । Psychology Today." Psychology Today: Health, Help, Happiness Find a Therapist. Psychology Today, 13 July 2010. Web. 19 Aug. 2010. $<$ http://www.psychologytoday.com/blog/imagin e/201007/thetraditioninnovation-conundrumfurther-reflections-the-unesco-2nd-worldconfe>.

Ryan, Marie-Laure. "Will New Media Produce New Narratives?" Narrative across Media: the Languages of Storytelling. Ed. Marie-Laure Ryan. Lincoln: University of Nebraska, 2004. Print.

Ryu, Semi. "Experimental Virtual Wayang I Semi Ryu." Home of Virtual Puppetry | Semi Ryu. Web. 19 Aug. 2010. < http://www.semiryu.net/ ?page_id $=140>$.

Ryu, Semi, Stefano Faralli, Paolo Bottoni, and Anna Labella. "From Traditional to Virtual Interactive Puppetry: A Comprehensive Approach." Diss. University of Rome "Sapienza" Abstract. Print.

Sfaralli. (2007, 10 November). Experimental Virtual Wayang [Video file]. Retrieved from http://www. youtube.com/watch?v=H1T77KP3ye0

Supriyono, Djumiran Ranta Admaja, Bambang Sukmo Pribadi, and Joko Susilo. Pedalangan. Vol. 1. Jakarta: Direktorat Pembinaan Sekolah Menengah Kejuruan, Direktorat Jenderal Manajemen Pendidikan Dasar Dan Menengah, Departemen Pendidikan Nasional, 2008. Print.

Ulbricht, H. Wayang Purwa; Shadows of the past. Kuala Lumpur: Oxford UP, 1970. Print. 
Wisanggeni2004. (2007，5 July). Wayang Kulit Dewa Ruci [Video file]. Retrieved fromhttp:// www.youtube.com/watch?v=IJGE3m7BEng.
Zehnneunacht. (2007, 28 August). Shadow Monsters [Video file]. Retrieved from http://www. youtube.com/watch?v=g0TOQo_7te4 